\title{
KEMAMPUAN MENYUNTING KARANGAN EKSPOSISI BERDASARKAN EJAAN, PILIHAN KATA, DAN KETERPADUAN PARAGRAF SISWA KELAS VII SMP MUHAMMADIAYAH 06 MEDAN TAHUN AJARAN 2016-2017
}

\author{
Nirmawan \\ Universitas Muslim Nusantara Al Washliyah \\ Jl. Garu II No. 93 Medan \\ Irmanirma90@gmail.com
}

\begin{abstract}
Abstrak
Ejaan yang disempurnakan adalah aturan utama dalam menggunakan bahasa secara tepat, maka EYD harus benar-benar dapat dipergunakan sesuai dengan ketentuan dan sistem yang telah ditetapkan, sebab dalam penggunaan EYD dalam wacana bisa menimbulkan makna yang berbeda jika tidak sesuai dengan aturan-aturan yang telah ditetapkan dan dapat menimbulkan makna ganda.Metode yang digunakan dalam penelitian ini adalah metode deskriptif dengan mengambil populasi yang sekaligus menjadi sampelnya. Sampelnya adalah siswa kelas VII SMP Muhammadiyah 06 Medan yang berjumlah 20 siswa. Untuk pengambilan data diberikan tes yaitu dengan jumlah soal 20, masing-masing soal memiliki 1 jawaban. Teknik analisis data yang digunakan adalah dengan menghitung nilai rata-rata siswa. Berdasarkan hasil dari penelitian analisis kesalahan EYD dalam wacana siswa kelas VII SMP Muhammadiyah 06 Medan tahun ajaran 2016-2017 menunjukkan bahwa siswa kelas VII SMP Muhammadiyah 06 Medan memiliki kemampuan "sangat baik". Hasil ini dapat dilihat dari nilai rata-rata yang diperoleh siswa yaitu 81, sesuai dengan kategori penilaian untuk kualitatif memiliki kualifikasi "sangat baik". Berdasarkan nilai pada rentang 80-100.
\end{abstract}

Kata Kunci: Analisis, Ejaan, Dan Wacana

\begin{abstract}
The Enhanced Spelling System is the main rule in using language appropriately, then ESS should really be used in accordance with the determination and system that have been established, because, using EYD in a discourse could lead to a different meaning if it does not accordance with the rules that have been established and can cause ambiguity. The method used in this research is descriptive method by taking the population as well as a sample. The sample is the seventh grade students of SMP Muhammadiyah 06 Medan totaling 20 students. It is applied a test to collect the data consisting about 20 items where each question has only one best answer. Data analysis technique used is to calculate the average value of students. Based on the research result in error analysis of EYD by the seventh grade students of SMP Muhammadiyah 06 Medan in academic year 2016-2017 school shows that the seventh grade students of SMP Muhammadiyah 06 Medan has the "very good" ability. This result can be seen from the average value obtained by the students in the amount of 81, in accordance with the qualitative assessment categories to qualify "excellent", based on the value in the range of 80-100.
\end{abstract}

Keywords: Analysis, Spelling, And Discourse

\section{PENDAHUluan}

1.1. Latar Belakang Masalah

Bahasa merupakan salah satu alat

komunikasi yang mampu menampung perasaan dan pikiran pemakainya, serta mampu menimbulkan salah pengertian antara penutur dan pendengar atau penulis dan pembaca. Tanpa adanya bahasa manusia tidak akan dapat berkomunikasi antara yang satu dengan 
yang lainnya. Keterampilan berbahasa sangat penting dalam kehidupan seharihari untuk saling berhubungan dengan cara berkomunikasi. Komunikasi dapat berupa komunikasi satu arah, dua arah, dan multi arah.

Kegiatan berbahasa meliputi kemampuan menyimak, berbicara, membaca, dan menulis. Untuk dapat membuat karangan dengan baik, maka sipengarang harus terampil berbahasa, yakni baik dari segi ejaan, pilihan kata, susuna kalimat yang digunakannya, dan keterpaduan paragraf harus tepat dan teratur. Karena tampa adanya keterampilan berbahasa yang baik akan menyebabkan imformasi atau maksud yang akan disampaikan kepada orang lain akan memberikan pemahaman dan penafsiran yang berbeda.

Menulis adalah menurunkan atau melukiskan lambang-lambang grafis yang menggambarkan suatu bahasa yang dipahami oleh seseorang sehingga orang lain dapat membaca lambang-lambang grafis tersebut. Begitu juga mengarang pada hakekatnya bukan sekedar menulis simbol-simbol grafis sehingga berbentuk kata, dan kata-kata tersusun menjadi kalimat menurut peraturan tertentu, akan tetapi mengarang adalah menuangkan buah pikiran ke dalam bahasa tulis melalui kalimat-kalimat yang dirangkai secara utuh, lengkap, dan jelas sehingga buah pikiran tersebut dapat dikomunikasikan kepada pembaca.

Secara singkat dapat dikatakan bahwa kegiatan karang mengarang, menggunakan bahasa tulis untuk menyatakan isi hati dan buah pikiran pengarang secara menarik kepada pembaca. Oleh karena itu selain menguasai topik dan permasalahnya yang akan ditulis. Penulis dituntut untuk mengusai komponen-komponen menulis diantaranya grafologi, stuktur, kosa kata, dan kelancaran.

Menyunting karangan merupakan bagian dari pembelajaran bahasa Indonesia, khususnya dalam pelajaran menulis. Maka jelaslah kegiatan berbahasa itu mempunyai hubungan yang erat dengan menyunting karangan. Dalam menyunting karangan terlebih dahulu harus memahami dua hal yang sangat penting yaitu memahami ejaan atau tanda baca dan memahami unsur kebahasaan diantaranya meliputi kata, kalimat dan paragraf. Tanpa menguasai itu semua maka sulit untuk menjadi penyunting.

Menyunting karangan karangan adalah memperbaiki tulisan atau naskah agar terhindar dari kesalahan sehingga layak dibaca atau layak terbit. Dalam menyunting karangan harus menguasai pengetahuan tentang kebahasaan dan pengetahuan tentang isi tulisan. Disamping itu harus menguasai ejaan, tanda baca, pilihan kata, keefektifan kalimat dan ketepatan paragraf sehingga memperoleh suntingan yang baik.

Kegiatan menyunting karangan merupakan langkah yang baik untuk menghadirkan karangan yang baik dan benar secara ketatabahasaan dan bernalar. Seorang penyunting yang baik, tentu memiliki kemampuan dalam hal penyusunan karangan yang benar, mengetahui jenis-jenis karangan dan karakternya masing-masing, kohesi dan koherensi yang digunakan oleh pengarang, serta keberanian untuk mengatakan salah atau benar berdasarkan teori yang dapat dipertanggungjawabkan. Setelah karangan selesai dikerjakan agar memperoleh hasil yang baik harus dilakukan penyuntingan. Sebelum diadakan penyuntingan, hendaknya diadakan kegiatan perbaikan terhadap naskah tersebut.. Penyuntingan ini fokusnya pada hal yang lebih mikro, seperti penggunaan bahasa: pilihan kata, kebenaran struktur kalimat, ketepatan transisi, penyingkatan/pemanjangan, ejaan, dan mekanis (masalah penggunaan tanda baca, format, dan struktur karangan). Pada kegiatan penyuntingan ini kita harus memberikan perhatian khusus terhadap beberapa hal, yaitu: katakata yang mempunyai awalan dan akhiran 
(pebelajar, memelajari). Kata yang menunjukkan makna jamak (misalnya banyak, sejumlah, beberapa) kata yang berulang saling, berkali-kali tingkatan intensitas (sangat, kurang, agak) penggunaan tanda baca, yang kecil sekali pun dapat mengganggu pengertian. Berikan pengertian pada ungkapan yang kelihatannya sama tetapi maknanya berbeda (tidak harus berbeda dengan harus tidak).

Dalam kehidupan sehari-hari, masih banyak pelajar yang kurang mampu menggunakan bahasa yang benar dan teratur baik dalam berdialog langsung ataupun dalam menulis, apalagi dalam menulis sebuah karangan, karena dalam menulis karangan antara ejaan, kata-kata, dan penyusunan kalimat harus mempunyai daya tarik bagi pembaca. Disamping itu juga harus ada keterpaduan antara paragraf yang satu dengan yang lainnya

Berdasarkan permasalahan di atas maka penulis ingin mengadakan penelitian dengan judul "Kemampuan Menyunting Karangan Eksposisi Berdasarkan Ejaan, Pilihan Kata, Dan Keterpaduan Paragraf Siswa Kelas VII SMP Muhammadiayah 06 Medan Tahun Ajaran 2016-2017."

1.2 Tujuan

Tujuan penulisan ini adalah untuk mengetahui proses dan hasil kemampuan siswa dalam kemampuan menyunting karangan eksposisi berdasarkan ejaan, pilihan kata, dan keterpaduan paragraf siswa kelas VII SMP Muhammadiayah 06 Medan Tahun ajaran 2016-2017."

1.3 Pendekatan Pemecahan Masalah

Pendekatan pemecahan masalah penulisan ini adalah pemahaman terhadap karangan eksposisi dan Ejaan Yang Disempurnakan dengan menggunakan model keterpaduan paragraf oleh Siswa kelas VII SMP Muhammadiyah 06 Medan.

\section{METODE}

Metode yang digunakan adalah metode deskriftif dengan pendekatan kuantitatif. Menurut Nazir (1988: 63) metode deskriptif adalah suatu metode yang digunakan untuk meneliti sekelompok manusia, suatu objek, suatu kondisi, suatu sistem pemikiran, dan suatu peristiwa pada masa sekarang. Penelitian ini menggambarkan kemampuan menyunting karangan eksposisi berdasarkan ejaan, pilihan kata, dan keterpaduan paragraf siswa kelas VII SMP Muhammadiyah 06 Medan Tahun Ajaran 2016-2017.

\section{HASIL DAN PEMBAHASAN}

Sebagaimana telah diuraikan pada bagian metode penelitian, bahwa alat yang digunakan untuk menyempurnakan data adalah tes.

Dalam pelaksanaan pengolahan data tes, penulis berpedoman atas dasar ketentuan sebagai berikut:

a. Penilaian/standar nilai adalah 0-100

b. Setiap satu nomor tes diberi skor satu dihitung dengan menghitung jumlah skor yang benar dibagi jumlah soal kemudian dikali 100.

c. Setiap nomor yang dijawab responden atau tidak dijawab tidak mempengaruhi nomor yang dijawab

d. Nilai akhir rata-rata siswa dihitung dengan menjumlahkan nilai siswa dibagi jumlah seluruh siswa.

Sesuai dengan ketentuan di atas setelah dilakukan tes terhadap siswa kelas VII Muhammadiyah 06 Medan Tahun Ajaran 2016-2017 dapat dilihat pada tabel berikut: 
Tabel 1

Skor Siswa Tentang Menyunting EYD dalam Wacana

\begin{tabular}{|l|c|l|l|}
\hline No & Nomor Responden & Skor & Nilai \\
\hline 1 & 01 & 17 & 85 \\
\hline 2 & 02 & 19 & 95 \\
\hline 3 & 03 & 16 & 80 \\
\hline 4 & 04 & 18 & 90 \\
\hline 5 & 05 & 15 & 75 \\
\hline 6 & 06 & 17 & 85 \\
\hline 7 & 07 & 19 & 95 \\
\hline 8 & 08 & 15 & 75 \\
\hline 9 & 09 & 18 & 90 \\
\hline 10 & 10 & 19 & 95 \\
\hline 11 & 11 & 18 & 90 \\
\hline 12 & 12 & 13 & 65 \\
\hline 13 & 13 & 16 & 80 \\
\hline 14 & 14 & 18 & 90 \\
\hline 15 & 15 & 19 & 95 \\
\hline 16 & 16 & 12 & 60 \\
\hline 17 & 17 & 13 & 65 \\
\hline 18 & 18 & 17 & 85 \\
\hline 19 & 19 & 12 & 60 \\
\hline 20 & 20 & 13 & 65 \\
\hline & Jumlah & 324 & 1620 \\
\hline
\end{tabular}

Tabel di atas memperlihatkan jumlah skor awal yang di peroleh seluruh siswa dalam tes tentang analisis kesalahan EYD dalam wacana adalah 1.620. Hasil tes yang dilakukan oleh penulis terhadap siswa dihitung berdasarkan jawaban yang benar saja. Misalnya: jumlah soal sebanyak 20 dan yang benar sebanyak 15 , maka nilai yang diperolah siswa adalah 75 , dengan cara pedoman ketentuan cara pengolahan data di atas yaitu, jumlah skor yang benar dibagi jumlah soal di kali seratus.

Untuk membuktikan kebenaran penghitungan data di atas penulis menghitung hasilnya berdasarkan rumus berikut ini:

$$
\begin{aligned}
\text { Mean } & =\frac{\sum X}{n} \\
\text { mean } & =\frac{1.620}{20} \\
& =81
\end{aligned}
$$

Keterangan:

$$
\begin{array}{cl}
\sum X & =\text { Jumlah nilai siswa } \\
\mathrm{N} & =\text { Jumlah siswa }
\end{array}
$$

Berdasarkan perhitungan di atas, maka hasil tes menyunting EYD dalam wacana diperoleh nilai rata-rata 81 . Setelah diperoleh nilai rata-rata tes menyunting EYD dalam wacana selanjutnya membandingkan nilai rata-rata tersebut dengan peringkat nilai yang sesuai dengan penggolongan angka rentangan 0 100 dalam petunjuk pelaksanaan sistem penilaian Suharsimi Arikunto (2006: 240) sebgai berikut:

$\begin{array}{ll}80-100 & : \text { sangat baik } \\ 66-79 & : \text { baik } \\ 56-65 & : \text { Sedang } \\ 40-55 & : \text { kurang } \\ 30-39 & : \text { kurang sekali } \\ \text { Berdasarkan } & \text { analisis yang }\end{array}$
dilakukan nilai yang diperoleh siswa adalah 81. Maka masuk dalam kategori nilai 80-100 tergolong "Sangat Baik". 
Berdasarkan pada data di atas dapat diketahui tentang menyunting EYD dalam wacana, skor yang tertinggi adalah 95 sebanyak 4 siswa, skor 90 sebanyak 4 siswa, skor 85 sebanyak 3 siswa, skor 80 sebanyak 2 siswa, skor 75 sebanyak 2 siswa, skor 65 sebanyak 3 siswa, dan skor terendah adalah 60 sebanyak 2 siswa.

\section{KESIMPULAN}

Berdasarkan penelitian yang dilakukan dapat diberikan beberapa kesimpulan sebagai berikut ini:

1. Pada umumnya menyunting EYD dalam wacana siswa kelas VII SMP Muhammadiyah 06 Medan Tahun Ajaran 2016-2017 tergolong sangat baik dengan nilai rata-rata 81 .

2. Menyunting EYD dalam wacana siswa kelas VII SMP Muhammadiyah 06 Medan Tahun Ajaran 2016-2017 belum seluruhnya tepat, tetapi jumlah yang benar sudah didominasi dari pada jumlah jawaban yang salah.

3. Siswa kelas VII MTs Muhammadiyah 06 Medan Tahun Ajaran 2016-2017 sudah memiliki pengetahuan tentang menyunting EYD dalam wacana yang memuaskan sesuai dengan yang diharapkan.

\section{DAFTAR PUSTAKA}

Suharsimi Arikunto. 2006. Prosedur Penelitian. Jakarta: Rineka Cipta.

Sugiyono. 2009. Metode Penelitian Pendidikan. Bandung: Alfabeta.

Otong Setiawan Djuharie dan Suherli. 2005. Panduan Membuat Karya Tulis. Bandung: Yrama Widya.

Departemen Pendidikan Nasional. 2006. Pedoman Umum Ejaan Bahasa Indonesia yang Disempurnakan dan Pedoman Umum Pembentukan Istilah. Bandung: Yrama Widya.

Pusat Bahasa Departemen Pendidikan Nasional. 2003. Buku Praktis Bahasa Indonesial. Jakarta: Seri Pedoman: pdm 003. 